\title{
Prevention of coxsackieviruses and rotaviruses infections in vivo with methanol extract of dodonaea
} viscosa

\begin{abstract}
Human coxsackievirus B3 (CVB3) and rotaviruses (RV), RNA viruses, are major heart and intestine pathogens in children, respectively. In the current study, we determined the effect of methanol extract from the leaves of Dodonaea viscosa against CVB3 and $\mathrm{RV}$ replication in vivo. BALB/c mice were injected intraperitoneally with CVB3 at 105 $\operatorname{TCID}_{50}\left(50 \%\right.$ tissue culture infective dose) or inoculated orally with RV at $106 \mathrm{TCID}_{50}$, inducing acute myocarditis and gastroenteritis in infected mice. After $24 \mathrm{~h}$ of infection, the infected mice with CVB3 or RV were treated orally with the methanol extract of Dodonaea viscoasa leaves for 7 days. We found that the extract protected the infected mice from deaths and reduced the viral titers in heart tissues and fecal specimens of mice infected with CVB3 and RV, respectively. Interestingly, the extract showed markedly improved cardiac tissues and small intestinal lesion scores of infected mice with CVB3 and RV, respectively. Moreover, the extract reduced the elevation of the lactic dehydrogenase, Creatine kinase, and aspartate transaminase enzymes in serum of CVB3 infected mice. Also, the extract reduced the duration of diarrhea in the infected mice with $\mathrm{RV}$, when compared with those in infected control. In our conclusion, the methanol extract could be used as strong therapeutic target for viral myocarditis and gastroenteritis caused by CVB3 and RV, respectively.
\end{abstract}

Volume 5 Issue 5 - 2017

\author{
Mohamed Shaheen,' Samy Mostafa, ${ }^{2}$ Nagwa \\ El Esnawy \\ 'Department, Environmental Research Divisions, National \\ Research Center, Egypt \\ 2Department of Medicinal and Aromatic Plants Research, \\ National Research Center, Egypt
}

\begin{abstract}
Correspondence: Mohamed Shaheen, Environmental Virology Laboratory, Water Pollution, Research Department, Environmental Research Divisions, National Research Center, Dokki, Giza, Egypt, Tel 201016710071, Emailm_nrc2007@yahoo.com
\end{abstract}

Received: February 13, 2017 | Published: July 14, 2017

Keywords: Coxsackieviruses, Rotaviruses, In Vivo, Antiviral, Dodonaea Viscosa

Abbreviations: AST, Aspartate Aminotransferase; BALB/c, An Albino, Laboratory-bred Strain of the House Mouse; BW, Body Weight; CAR, Coxsackie and Adenoviruses Receptor; CK, Creatine Kinase; DCM, Dilated Cardiomyopathy; DMEM, Dulbecco's Modified Eagle Medium; EMEM, Eagle's Minimum Essential Medium; GMK, Green Monkey Kidney; HW, Heart Weight; LDH, Lactate Dehydrogenase; NRC, National Research Centre; PFU, Plaque-Forming Unit; SD, Standard Deviation; V/C, Villi/Crypt

\section{Introduction}

Human coxsackievirus B3 (CVB3), belonging to the genus Enterovirus within the family of Picornaviridae, is the most common pathogen of acute viral myocarditis in human, particularly children and adolescents. ${ }^{1-3}$ CVB 3 can cause wide range of symptoms such as fever, gastrointestinal, headache, distress, muscle pain, and chest pain ${ }^{4}$ Acute myocarditis due to CVB3 infection can result in chronic heart failure and dilated cardiomyopathy (DCM), which mostly requires cardiac transplantation. ${ }^{2,5}$ Also, CVB3 infections can cause serious diseases affecting the central nervous system or pancreas. ${ }^{6,7}$ Unfortunately, to date, there are no specific antiviral or therapeutic agents for treatment and/or prevention of the diseases resulted from CVB3 infections. ${ }^{8}$ Rotavirus (RV), belonging to the Reoviridae family, is the single most important cause of severe diarrheal disease especially in infant and young children, worldwide. ${ }^{9} 10 \mathrm{RV}$ is responsible for 114 million diarrhea episodes, 25 million clinic visits, 2.4 million requiring hospitalization, and over 500,000 deaths per year, usually children $<5$ years of age, worldwide. ${ }^{11}$ To prevent RV infection, two rotavirus vaccines, RotaTeq and Rotarix, are currently licensed in many countries. ${ }^{12,13}$ However, the high cost of this vaccine production limits their application in developing countries. ${ }^{14}$ Therefore, cheap and effective drugs are urgent to control theses disease, particularly in developing countries. Several researchers, including our group, have been determined the antiviral activity of natural compounds from food and herbal extracts. ${ }^{15}$ Several natural compounds and herbal extracts have been reported to possess antiviral activity against coxsackievirus B3 and rotavirus infections in vitro and in vivo. ${ }^{16-24}$ So, they may be ideal sources for preventive and control these virus infections. Dodonaea viscosa, belonging to Spindaceae family, is known to contain several constituents such as flavonoids, sesquiterpenes, triterpenes, coumarins, monoterpenes, diterpenes, and steroids. ${ }^{25-28}$ The plant has been used to cure skin disease..$^{29}$ Various biological activities such as antimalarial, antibacterial, anti-diarrheal, analgesic, antiulcer, antiviral, antidiabetic, anti-inflammatory, and antioxidant. ${ }^{19,30-36}$ activities are observed from this plant. In the present study we will evaluate the antiviral activity of methanol extract from Dodonaea viscosa leavesagainst coxsackieviruses and rotaviruses infections in vivo.

\section{Materials and methods}

\section{Plant collection}

The leaves of $D$. viscosa were collected during May and June 2011, from the botanical garden of the National Research Centre (NRC), Giza, Egypt. The plant was kindly identified by Dr. Mona Marzok, researcher at NRC.

\section{Extracts preparation}

The methanol extract of $D$. viscosa leaves was prepared as described by Shaheen et al..$^{22}$ In brief, after drying the leaves at room temperature, the leaves were dissolved in methanol and concentrated till dryness at $40 \mathrm{oC}$ in a rotary evaporator. The dried extract was weighted to estimate the percentage yield (concentration). To prepare the stock solution, $100 \mathrm{mg}$ of the lyophilized extract was dissolved in $0.5 \mathrm{ml}$ distilled Dimethyl sulphoxide (DMSO) then the volume was made up to ten milliliter with Eagle's minimum essential medium (EMEM) or Dulbecco's Modified Eagle Medium (DMEM). The stock 
solution was passed through membrane filtration (Millipore $0.45 \mu \mathrm{m}$ ) for sterilization, and then stored in a refrigerator at $4 \mathrm{oC}$ until use.

\section{Cell lines and viruses}

Green monkey kidney cell line (GMK) with CVB3 were provided by Prof. Dr. Shubhada Bopegamage (National Reference Center of the Enter virus Laboratory, Faculty of Medicine, Slovak Medical University), under SAIA program. While Rhesus monkey kidney cell line (MA 104) and Simian rotavirus SA-11 were provided Prof. Mamta Chawla-Sarker (Department of Virology, National Institute for Cholera and Enteric Diseases, Kolkata, India), under INSAJRD TATA program. The both cell lines were grown in EMEM and DMEM, respectively.

\section{Virus titration}

The GMK and MA 104 monolayers were infected with CVB3 and activated RV SA-11with trypsin $(10 \mathrm{mg} / \mathrm{ml})$ for $30 \mathrm{~min}$ at $37 \mathrm{oC}$ ), respectively. The viral titers were estimated as $\mathrm{TCID}_{50} / 0.1$ $\mathrm{ml}(50 \%$ tissue culture infectious doses $/ 0.1 \mathrm{ml})$ by using standard Spearman Kärber formula. ${ }^{34}$ For our antiviral experiments, we used $10^{4} \log _{10} \mathrm{TCID}_{50} / 0.1 \mathrm{ml}$ and $10^{6} \log _{10} \mathrm{TCID}_{50}$ for CVB3 and RV, respectively.

\section{Cytotoxic effect of the extract in mice}

Forty specific-pathogen-free BALB/c male mice, 1- 4 weeks old $(10-15 \mathrm{~g})$, were obtained from the animal center of the $\mathrm{NRC}$, were used in this experiment. The mice were divided into 5 groups $(n=8$ per group), four groups were treated with four different concentrations $(400,300,200,100 \mathrm{mg} / \mathrm{kg} /$ body weight $)$ of the methanol extract via oral gavage for 7 days. Group $(n=8)$ was treated with the same volume of phosphate buffer saline as negative control. The mice were monitored for deaths daily for 3 weeks.

\section{Antiviral activity of methanol extract of $D$. viscosa on CVB3 and RV SA-I I infection in mice}

For each virus, forty BALB malemice(1-4 weeks old) were used. The mice for each virus were distributed to five groups (8 mice per group). Among them, four groups were infected intraperitoneally with CVB3 $\left(10^{5} \mathrm{TCID}_{50} / 0.1 \mathrm{ml}\right)$ or orally with $\mathrm{RV}\left(106 \mathrm{TCID}_{50} / 0.1 \mathrm{ml}\right)$ as fellow: Infected group with virus/ inoculated orally with ribavirin at $10 \mathrm{mg} / \mathrm{kg}$ body weight as treated positive control.

a. Infected group with virus/ inoculated orally with $0.9 \%$ saline solution as untreated positive control.

b. Infected group with virus/ inoculated orally with methanol extract at $100 \mathrm{mg} / \mathrm{kg}$ body weight.

c. Infected group with virus/ inoculated orally with methanol extract at $50 \mathrm{mg} / \mathrm{kg}$ body weight.

d. Non-infected group / inoculated orally with $0.9 \%$ saline solution as negative control.

e. For the four infected groups, the treatment either with ribavirin, $9 \%$ saline solution, or extract was applied at 24 post-infection.

For the group infected with CVB3: After 7 days of virus exposure, 4 mice from each group were subjected to blood collections from their eye socket and the activities of the lactic dehydrogenase, Creatine kinase, and aspartate transaminase enzymes were determined in the serum according to attached protocols found in purchase kits. From each mice, the heart tissues were collected to measure the ratios of body weight (BW) and heart weight (HW). Afterwards, the heart was divided into 2 parts; one to determine the viral titers of virus using plaque assay as described by Bishop and Koch. ${ }^{37}$ The second part of heart was subjected to histopathological examination to score the myocardial necrosis as follows: $0=$ no infiltration or necrosis, $1=1 \%$ - $25 \%$ infiltration or necrosis, $2=26 \%-50 \%$ infiltration or necrosis, $3=51 \%-74 \%$ infiltration or necrosis, and $4=75 \%-100 \%$ infiltration or necrosis. ${ }^{38}$

For the group infected with RV: During the period of treatment, we monitored the mortality, duration of diarrhea, and severity of diarrhea according to Shaw et al..$^{39}$ based on 5 points as fellow: $0=$ normal, solid and black, $1=$ soft brown, 2 = liquid brown, 3 = soft yellow, and 4 = liquid yellow. Also, the feces of each group were collected and pooled daily subjected to plaque assay to estimate the vial titers. ${ }^{40}$ At 7 days post-infection, four mice from each group were killed and the small intestine of each group were collected for histopathological examinations. The changes in small intestinal were scored as described by Kim et al. ${ }^{41}$ Based on the ratios of villi/crypt $(\mathrm{V} / \mathrm{C})$ which estimated as follows: $0=$ normal, $1=$ mild, $2=$ moderate, $3=$ marked and $4=$ severe. The remaining mice in all groups were used for recording the deaths for additional one week.

\section{Statistical analysis}

Quantitative data were statistically represented as mean \pm standard deviation (S.D.). Comparison between difference groups in the present study was done using One-way analysis of variance (ANOVA) test as comparison between more than two parametric groups with Dunnett and Duncan as multiple comparisons. A probability value ( $\mathrm{p}$ value) less than or equal to $(0.05)$ was considered significant. All statistical calculations and graphs were done using computer program SPSS (Statistical Package for Social Science) statistical program version (16.0) and Microsoft Excel program version (2010).

\section{Results}

\section{Cytotoxic effect of methanol extract of $D$. viscosa on mice}

As depicted in (Table 1). The survival rate was $100 \%$ and no mortality was observed in the group of mice treated with the methanol extract at $100 \mathrm{mg} / \mathrm{kg}$ body weight. So, we used 100 and $50 \mathrm{mg} / \mathrm{kg}$ body weight as two safe doses in mice to be used in our antiviral experiments.

\section{Antiviral Effect of Methanol extract of D. viscosa against CVB3 in Mice}

Morbidity, mortality, and HW/BW ratios in infected mice: As shown in (Table 2). The mice treated with the extract at 100 and 50 $\mathrm{mg} / \mathrm{kg}$ body weight showed less morbidity when compared with the infected control. Also, the extract at the both dosages protected the treated mice from deaths resulted from CVB3 infection, compared with the infected control. On the other hand, the HW/BW ratios were also significantly decreased in mice treated with the extract at 100 and $50 \mathrm{mg} / \mathrm{kg}$ body weight when compared with those in the infected control.

Virus titers in heart tissues: Virus titers in the infected heart cells without treatment were $6.12 \pm 0.03$, cells, which reduced significantly to $4.23 \pm 0.02$ and $4.27 \pm 0.04$ in cells treated with the methanol extract at 100 and $50 \mathrm{mg} / \mathrm{kg}$ body weight, respectively (Table 2), indicating that this extract has potent antiviral effect against CVB3.

Effects of methanol extract on LDH, AST, and CK in infected murine serum: At 7 days post-infection, the activities of LDH, AST, and $\mathrm{CK}$ in the serum of the treated mice with the extract were very 
close to those in the normal control, which significantly increased in the infected mice without treatment (Figure 1).
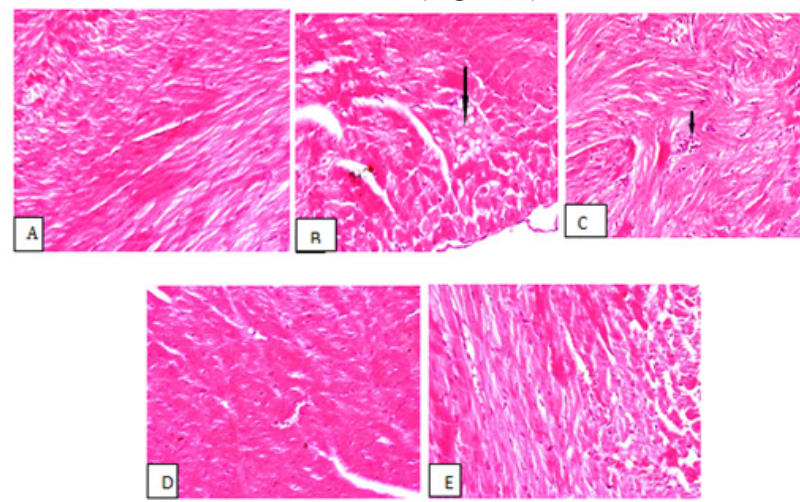

Figure I Stained sections of the heart tissues from BALB/c mice (H\&E, magnification $200 \mathrm{X}$ ): A: non-infected and non-treated mice; B: infected and non-treated mice; C: RBV mice; $D$ : infected mice with RV and treated with the methanolic extract of $D$. viscosa at $100 \mathrm{mg} / \mathrm{kg}$ body weight; $E$ : infected mice with RV and treated with the methanolic extract of $D$. viscosa at $50 \mathrm{mg} /$ $\mathrm{kg}$ body weight.

\section{Pathological evaluation}

Scores of necrosis and filtration were $0.25 \pm 0.01$ and $0.25 \pm$ 0.01 in the treated mice with the methanol extract at 100 and $50 \mathrm{mg} /$ $\mathrm{kg}$ body weight, respectively. However, the necrosis and filtration were significantly increased to $3.25 \pm 0.10$ in infected mice without treatment (Table 2). On the other hand, the cell infiltration and necrosis were obvious in infected control, which greatly reduced in the mice treated with the extract at the both dosages at 7 days post-infection (Figure 2A-2E)

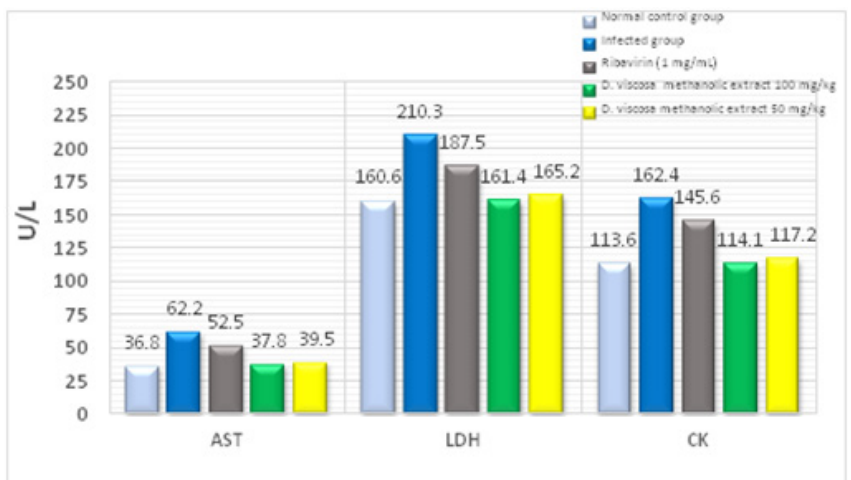

Figure 2 Histogram showing the effects of methanolic extract of $D$. viscosa leaves on the activities of AST, LDH, and CK in different groups of mice. Serum levels of $\mathrm{LDH}$ and $C K$ were measured at day $7 . n=4$ for each group. ** $P<0.01$ versus the CVB3-infected group.

\section{Antiviral Effect of Methanol extract of D. viscosa against RV in Mice}

Mortality: The methanol extract at the both dosages protected the treated mice from the deaths resulted from RV diarrhea. However, 75 $\%$ of infected mice without treatment were dead, which decreased to $50 \%$ in ribavirin treated group.

Severity and duration of diarrhea: The severity of diarrhea in the infected control was $4 \pm 0.03$, which significantly reduced to $3.37 \pm 0.03$ and 3.50 \pm 0.04 in the group of mice treated with the methanol extract at 100 and $50 \mathrm{mg} / \mathrm{kg}$ body weight, respectively. On the other hand, the extract recovered the treated mice from RV diarrhea in shorter time, compared to those that did not receive the methanol extract (Table 3 ).
Virus titers in feces of infected mice: As shown in (Table 3) the methanol extract greatly reduced the virus titers to $0.97 \pm 0.02$ and $1.55 \pm 0.01$ at 100 and $50 \mathrm{mg} / \mathrm{kg}$ body weight, respectively. Whereas, the virus titers in the feces of infected mice without receiving extract was higher (6.2 \pm 0.05$)$.

Histologic Examination: The lesion scores in treated mice were cores were greatly lower than those in infected control (Table 3). On the other hand, the lesions in the small intestine villi including dropsy and vacuolar degeneration were greatly reduced in mice treated with the extract at the both dosages, compared to those in infected control (Figure 3-3E)

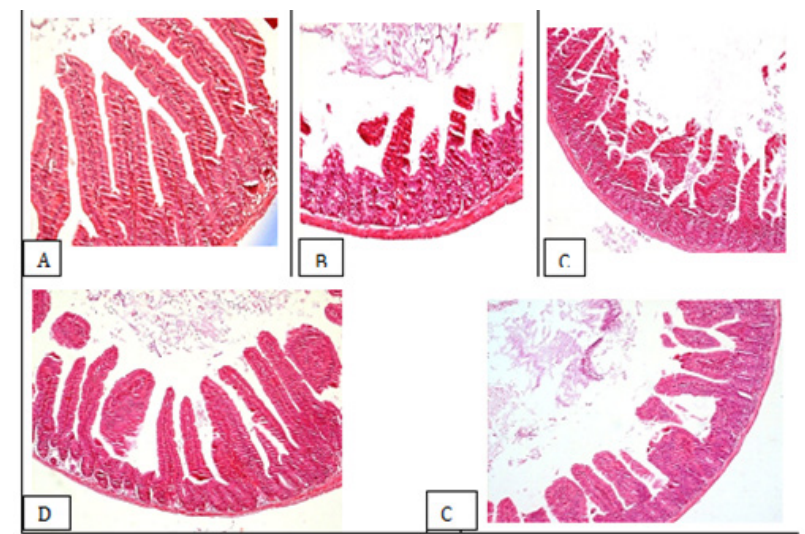

Figure 3 Stained sections of small intestine tissues from BALB/c mice (H\&E, magnification $200 \mathrm{X}$ ): A: non-infected and non-treated mice; B: infected and non-treated mice; C: RBV mice; D: infected mice with RV and treated with the methanolic extract of $D$. viscosa at $100 \mathrm{mg} / \mathrm{kg}$ body weight; E: infected mice with RV and treated with the methanolic extract of $D$. viscosa at $50 \mathrm{mg} /$ $\mathrm{kg}$ body weight.

\section{Discussion}

The cytotoxic effect of ingestion of $D$. viscosa methanolic extract to mice was evaluated at various concentrations $(100,200,300$, and $400 \mathrm{mg} / \mathrm{kg}$ body weight), for seven days. Our results demonstrated that the extract is safe to mice at $100 \mathrm{mg} / \mathrm{kg}$ body weight and therefore we chosen 100 and $50 \mathrm{mg} / \mathrm{kg}$ body weight as two safe doses to be tested against CVB3 and RV infections. Our previous work suggested that the methanol extract of $D$. viscoasa has antiviral activity against CVB3 and RV in vivo. ${ }^{19}$ In this study, we demonstrated that this extract has also antiviral activity against both viruses in vivo, protecting the infected mice against viral myocarditis and gastroenteritis resulted from CVB3 and RV infections, respectively. To detect the protective effect of methanol extract against CVB3 myocarditis and RV gastroenteritis, Nancy strain of CVB3 and simian RV strain SA11 were used to induce mild myocarditis and sever gastroenteritis in infected mice, respectively. In the treated mice daily with the extract after infection with CVB3, morbidity, virus titers, HW/BW, scores of pathologic, and mortality were significantly reduced than those in infected controls. In addition, the extract was significantly alleviated mononuclear cell infiltration and necrosis in the hearts of treated mice compared to infected controls. Moreover, the harmful effect of CVB3 myocarditis can lead to increase in the activity of AST, LDH, and CK enzymes. ${ }^{42}$ Interestingly, our extract kept the activities of these enzymes at normal values in the serum of treated mice, when compared with infected controls. These findings suggest that this extract has strong antiviral effect against CVB3 in vivo and can be used as therapeutic drug for viral myocarditis. Although, the mechanism by which the extract can inhibit CVB3 replication in vivo is not known, our previous work suggested that the methanol 
extract inhibited CVB3 replication in vitro by binding the extract to viral cased. ${ }^{19}$ Furthermore, it has been reported that coxsackie and adenoviruses receptor (CAR) serve as receptor for CVB3 infection. ${ }^{43}$ So, the methanol extract may be hindered the binding of virus to CAR, preventing its entry into host cells in the treated mice. On the other hand, oral inoculation of the methanol extract of D. viscosa after infection of newborn mice with RV showed lower mortality, rapid recovery from diarrheal disease, and lower virus titer than those in infected control. Moreover, the villi of the small intestine were higher in the treated group with the methanol extract when compared to mice that didn't receive the methanol extract. Although we didn't study how the extract can block RV infection in vitro but in our previous work we demonstrated that this extract suppressed RV replication in vitro by blocking the viral receptors. ${ }^{19}$ Saponin has be identified in the ethanol extract of $D$. viscosa leaves ${ }^{44}$ Saponin has been reported to suppress RV infection by preventing virus-host attachment, reducing the mortality, severity, and duration of diarrhea in infected mice with $\mathrm{RV}^{45}$

Table I Cytotoxicity results of methanolic extract of $D$. viscosa in vivo

\begin{tabular}{|c|c|c|c|c|}
\hline Group of Mice & Concentrations/Kg Body Weight/Day & Number Of Dead Animals & Survival Rate & Mortality Rate \\
\hline Control & 0 & 0 & $100 \%$ & $0 \%$ \\
\hline \multirow{4}{*}{ Methanolic extract of $D$. viscosa } & $100 \mathrm{mg}$ & 0 & $100 \%$ & $0 \%$ \\
\hline & $200 \mathrm{mg}$ & I & $87.50 \%$ & $12.50 \%$ \\
\hline & $300 \mathrm{mg}$ & 2 & $75 \%$ & $25 \%$ \\
\hline & $400 \mathrm{mg}$ & 4 & $50 \%$ & $50 \%$ \\
\hline
\end{tabular}

Table 2 Effect of Methanolic extract D. viscosa on morbidity, mortality, the heart index, virus titers, and pathologic scores after 7 days from inoculation of BALB/ mice with CVB3

\begin{tabular}{lllll}
\hline Group & Morbidity (\%) & Mortality (\%) & $\begin{array}{l}\text { HW/BW Ratios } \\
\text { (Mean } \pm \text { SD) }\end{array}$ & $\begin{array}{l}\text { Virus Titration(Log I P PFU/ } \\
\text { MI, Means } \pm \text { SD) }\end{array}$ \\
\hline Normal control group & 0 & 0 & $4.21 \pm 0.02$ & 0 \\
(Mean \pm SD)
\end{tabular}

a. $P$ value of the comparison between the all different groups without the normal control group.

b. $* * \mathrm{P} \leq 0.0 \mathrm{I}$ value of the comparison between each group with the infected group.

Table 3 Results of severity and duration of diarrhea, virus titers, lesion score of small intestine, and mortality in different groups of mice

\begin{tabular}{|c|c|c|c|c|c|c|}
\hline \multirow[b]{2}{*}{ Group of Mice } & \multirow[b]{2}{*}{ Mortality } & \multicolumn{3}{|l|}{ Diarrhea } & \multirow[b]{2}{*}{$\begin{array}{l}\text { Virus Titers (Log I Opfu/MI, } \\
\text { Means } \pm \text { SD) }\end{array}$} & \multirow[b]{2}{*}{$\begin{array}{l}\text { Lesion Score } \\
\text { (Means } \pm \text { SD) }\end{array}$} \\
\hline & & $\begin{array}{l}\text { Number of } \\
\text { mice developed } \\
\text { diarrhea }\end{array}$ & $\begin{array}{l}\text { Severity } \\
\text { (Diarrhea } \\
\text { scores } \pm \text { S.D.) }\end{array}$ & $\begin{array}{l}\text { Duration } \\
\text { of diarrhea } \\
\text { (Days } \pm \text { S.D.) }\end{array}$ & & \\
\hline Normal control group & 0 & 0 & 0 & 0 & 0 & 0 \\
\hline Infected group & $75 \%$ & 8 & $4 \pm 0.03$ & $6.2 \pm 0.05$ & $6.50 \pm 0.05$ & $3.75 \pm 0.0 \mathrm{I}$ \\
\hline Ribavirin I mg/mL) & $50 \%$ & 8 & $3.87 \pm 0.02 * *$ & $3.6 \pm 0.11 * *$ & $3.13 \pm 0.03 * *$ & $3.0 \pm 0.07^{* *}$ \\
\hline Extract at $100 \mathrm{mg} / \mathrm{kg}$ & 0 & 8 & $3.37 \pm 0.03 * *$ & $2.5 \pm 0.05 * *$ & $0.97 \pm 0.02 * *$ & $1.25 \pm 0.04 * *$ \\
\hline Extract at $50 \mathrm{mg} / \mathrm{kg}$ & 0 & 8 & $3.50 \pm 0.04 * *$ & $2.4 \pm 0.03 * *$ & $1.55 \pm 0.01 * *$ & $1.5 \pm 0.02 * *$ \\
\hline
\end{tabular}

a. $P$ value of the comparison between the all different groups without the normal control group.

b. $* * P \leq 0.0$ I value of the comparison between each group with the infected group.

Moreover, we determined the presence of phenolic and flavonoid compounds in the methanolic extract of $D$. viscosa leaves, we find that the plant contains high percentage of total phenolics $15.58 \% / 100 \mathrm{mg}$ and low percentage of flavonoid compounds $(1.33 \% / 100 \mathrm{mg})$, data have not been shown. These compounds showed antiviral activity against several RNA viruses, among them CVB3 and RV. ${ }^{46,47}$ So, the inhibition of CVB3 and RV may be attributed to presence of such compounds in D. viscosa leaves. Finally, further studies are needed to isolate the bio-active compounds and to understand the exact mechanism by which these compounds can inhibit CVB3 and RV infections in vivo.

\section{Conclusion}

Our data showed that the methanol extract of $D$. viscosa leaves had potentially antiviral activity against coxsackievirus B3- induced myocarditis and rotavirus-induced gastroenteritis in mice, suggesting that this extract may represent a potentially novel therapeutic candidate for the treatment of viral myocarditis and gastroenteritis due to CVB3 and RV infections in human.

\section{References}

1. Kim BK, Kim JH, Kim NR, Lee WG, Lee SD, et al. (2012) Development of anti-coxsackievirus agents targeting $3 \mathrm{C}$ protease. Bioorg Med Chem Lett 22(22): 6952-6956.

2. Koho T, Koivunen MR, Oikarinen S, Kummola L, Mäkinen S, et al. (2014) Coxsackievirus B3 VLPs purified by ion exchange chromatography elicit strong immune responses in mice. Antiviral Res 104: 93-101. 
3. Yuan J, Stein DA, Lim T, Qiu D, Coughlin S, et al. (2006) Inhibition of coxsackievirus B3 in cell cultures and in mice by peptide-conjugated morpholino oligomers targeting the internal ribosome entry site. J Virol 80(23): 11510-11519.

4. Lee CC, Kuo CJ, Ko TP, Hsu MF, Tsui YC, et al. (2009) Structural basis of inhibition specificities of $3 \mathrm{C}$ and $3 \mathrm{C}$-like proteases by zinccoordinating and peptidomimetic compounds. Journal of Biological Chemistry 284(12): 7646-7655.

5. Selinka HC, Wolde A, Sauter M, Kandolf R, Klingel K (2004) Virusreceptor interactions of coxsackie $B$ viruses and their putative influence on cardiotropism. Medical microbiology and immunology 193(2-3): 127-131.

6. Feuer R, Mena I, Pagarigan RR, Harkins S, Hassett DE, et al. (2003) Coxsackievirus B3 and the neonatal CNS: the roles of stem cells, developing neurons, and apoptosis in infection, viral dissemination, and disease. The American journal of pathology 163(4): 1379-1393.

7. Mena I, Fischer C, Gebhard JR, Perry CM, Harkins S, et al. (2000) Coxsackievirus infection of the pancreas: evaluation of receptor expression, pathogenesis, and immunopathology. Virology 271(2): 276288.

8. Lee ES, Lee WG, Yun SH, Rho SH, Im I, et al. (2007) Development of potent inhibitors of the coxsackievirus $3 \mathrm{C}$ protease. Biochemical and biophysical research communications 358(1): 7-11.

9. Estes MK, Kapikian AZ (2007) Rotaviruses. In: Knipe DM, et al. (Eds.), Fields Virology. 5th (edn), USA.

10. Junaid SA, Umeh C, Olabode AO, Banda JM (2011) Incidence of rotavirus infec-tion in children with gastroenteritis attending Jos university teaching hospital, Nigeria. Virol J 8: 233.

11. Kotloff KL, Nataro JP, Blackwelder WC, Nasrin D, Farag TH, et al. (2013) Burden and aetiology of diarrhoeal disease in infants and young children in developing countries (the Global Enteric Multicenter Study, GEMS): a prospective, case-control study. Lancet 382(9888): 209-222.

12. Bernstein DI (2006) Live attenuated human rotavirus vaccine, Rotarix ${ }^{\mathrm{TM}}$, Semin Pediatr Infect Dis 17(14): 188-194.

13. Matson DO (2006) The pentavalent rotavirus vaccine, Rotateq ${ }^{\mathrm{TM}}$, Seminars in pediatric infectious diseases. Elsevier 195-199.

14. Madsen LB, Ustrup M, Fischer TK, Bygbjerg IC, Konradsen F (2012) Reduced price on rotavirus vaccines: enough to facilitate access where most needed? Bulletin of the World Health Organization 90(7): 554-556.

15. Lipson SM, Sethi L, Cohen P, Gordon RE, Tan IP, et al. (2007) Antiviral effects on bacteriophages and rotavirus by cranberry juice. Phytomedicine 14(1): 23-30.

16. Birdi TJ, Daswani PG, Brijesh S, Tetali P (2011) In vitro antigiardial and antirotaviral activity of Psidium guajava L. leaves. Indian J Pharmacol 43(5): 616-617.

17. Knipping K, Garssen J, van't Land B (2012) An evaluation of the inhibitory effects against rotavirus infection of edible plant extracts. Virol J 9: 1-137.

18. Liu Q, Wang YF, Chen RJ, Zhang MY, Wang YF, et al. (2009) Anticoxsackie virus B3 norsesquiterpenoids from the roots of Phyllanthus emblica. Journal of natural products 72(5): 969-972.

19. Shaheen M, El-Gamal M, Mousa A, Mostafa S, El-Esnawy N (2014) Anti-Rotaviral Effects of Bauhinia variegata methanolic extract in mice with rotavirus diarrhea. Middle East Journal of Applied Sciences 4(3): $555-562$.

20. Shaheen M, El-Gamal M, Mousa A, Mostafa S, El-Esnawy N (2014) Inhibition of Coxsackie virus B3 in mice by methanolic extract of Calliandra haematocephala. Journal of Microbiology, Biotechnology, and Food Sciences 4(3): 257-262.
21. Shaheen M, El-Gamal M, Mousa A, Mostafa S, El-Esnawy N (2014) Antiviral activity of Bauhinia variegata extracts against rotavirus in vitro. Current Science International 3(3): 172-178.

22. Shaheen M, Borsabyiova M, Mostafa S, Chawla-Sarkar M, Bopegamage $\mathrm{S}$, et al. (2015) In vitro effect of Dodonaea viscosa extracts on the replication of coxsackievirus B3 (Nancy) and rotavirus (SA-11), Microbiology and Antimicrobial Agents 1(2): 47-54.

23. Shaheen M, Mostafa S, El-Esnawy N (2015b) Anti-rotaviral effects of Calliandra haematocephala leaf extracts in vitro and in vivo. J Virol Antivir Res 4(2).

24. Shaheen M, Mostafa S, El-Esnawy N (2015) In vitro and in vivo antirotaviral activity of C. alata extracts. Journal of Research in Applied Sciences 2(3): 63-71.

25. Ahmad V, Fatima I, Fatima A (1987) The sapogenins from Dodonaea viscosa. Fitoterapia 58: 361-362.

26. Khan M, Javed K, Khan MH (1992) Constituents of the flowers of Dodonaea viscosa. Fitoterapia 63: 83-84.

27. Sachdev K, Kulshreshtha DK (1984) Dodonic acid, a new diterpenoid from Dodonaea viscosa. Planta Med 50(5): 448-449.

28. Zielinska M, Kostrzewa A, Ignatowicz E, Budzianowski J (2001) The flavonoids, quercetin and isorhamnetin 3-O-acyl-glucosides diminish neutrophil oxidative metabolism and lipid peroxidation. Acta Biochim Pol 48(1): 183-189.

29. Pirzada A, Shaikh W, Usmanghani K, Mohiuddin E (2010) Antifungal activity of Dodonaea viscosa Jacq extract on pathogenic fungi isolated from superficial skin infection. Pak J Pharm Sci 23(3): 337-340.

30. Alagarsamy V, Venket NR, Thangathirupathy A, Amuthalakshmi S, Sivakamisundari P (2007) Antiinflammatory activity of Dodonaea viscosa Linn leaf extracts. Indian Drugs-Bombay 44: 559.

31. Anilreddy B (2009) Preparation, characterization and biological evaluation of some overview of Dodonaea viscosa Linn. J Pharm Sci Technol 1: 1-9.

32. Clarkson C, Maharaj VJ, Crouch NR, Grace OM, Pillay P, et al. (2004) In vitro antiplasmodial activity of medicinal plants native to or naturalised in South Africa. J Ethnopharmacol 92(2-3): 177-191.

33. Khalil N, Sperotto J, Manfron M (2006) Antiinflammatory activity and acute toxicity of Dodonaea viscosa. Fitoterapia 77: 478-480.

34. Pengelly A (2008) Medicinal Activity of Dodonaea Viscosa: A Preliminary Study. Rural Industries Research and Development Corporation, Australia, p. 27-28.

35. Rajamanickam V, Rajasekaran A, Anandarajagopal K, Sridharan D, Selvakumar K, et al. (2010) Anti-diarrheal activity of Dodonaea viscosa root extracts. Int J Pharm Bio Sci 1(4): 182-185.

36. Veerapur VP, Prabhakar KR, Kandadi MR, Srinivasan KK, Unnikrishnan MK (2010) Antidiabetic effect of Dodonaea viscosa aerial parts in high fat diet and low dose streptozotocin-induced type 2 diabetic rats: A mechanistic approach. Pharm Biol 48(10): 1137-1148.

37. Bishop JM, Koch G (1969) Plaque assays for poliovirus and poliovirus specific RNAs. In: Habel K, Salzman NP, (Eds.), Fundamental Techniques in Virology, Academic Press, New York, USA, pp. 131-145.

38. Zhang Y, Hang Y, Haiyan Z, Chenggang H, Xiaolan C, et al. (2006) Astragaloside IV Exerts Antiviral Effects Against Coxsackievirus B3 by Upregulating Interferon gamma. J Cardiovasc Pharmacol 47(2): 190195.

39. Shaw RD, Hempson SJ, Mackow ER (1995) Rotavirus diarrhea is caused by non replicating viral particles. J Virol 69(10): 5946-5950.

40. Belinelo VJ, Tacchi CMS, Antunes RM, Assenco RAG, Vieira FSA (2013) Insignificant level of in vitro cytotoxicity, anti rotavirus, antibacterial, and antifungal, activities of $\mathrm{N}$ alkylmaleamic acids. $\mathrm{J}$ of Pharmaceutical Negative Results 4: 19-25. 
41. Kim HJ, Park JG, Matthijnssens J, Lee JH, Bae YC (2011b) Intestinal and extra-intestinal pathogenicity of a bovine reassortant rotavirus in calves and piglets. Vet Microbiology. 152(3-4): 291-303.

42. Wang H, Ding Y, Zhou J, Sun X, Wang S (2009) The in vitro and in vivo antiviral effects of salidroside from Rhodiola rosea L. against coxsackievirus B3. Phytomedicine : international journal of phytotherapy and phytopharmacology 16: 146-155.

43. Crowell RL (1966) Specific cell-surface alteration by enteroviruses as reflected by viral-attachment interference. Journal of bacteriology 91(1): 198-204.

44. Venkatesh S, Reddy Y, Ramesh M, Swamy M, Mahadevan N, et al. (2008) Pharmacognostical studies on Dodonaea viscosa leaves. African Journal of Pharmacy and Pharmacology 2(4): 83-88.
45. Tam KI, Roner MR (2011) Characterization of in vivo anti-rotavirus activities of saponin extracts from Quillaja saponaria Molina. Antiviral research 90(3): 231-241.

46. Bae EA, Han MJ, Lee M, KIM DH (2000) In vitro inhibitory effect of some flavonoids on rotavirus infectivity. Biological and Pharmaceutical Bulletin 23(9): 1122-1124.

47. Zhu H, Zhang Y, Ye G, Li Z, Zhou P (2009) In Vivo and in Vitro Antiviral Activities of Calycosin-7-O-. BETA.-D-glucopyranoside against Coxsackie Virus B3. Biological and Pharmaceutical Bulletin 32(1): 68-73. 